\title{
EXTRACTIVE SPECTROPHOTOMETRIC METHOD FOR THE DETERMINATION OF CARBARYL IN ENVIRONMENTAL SAMPLES
}

\author{
Devender Kumar Sharma ${ }^{1}$, Tilak Dharmani ${ }^{1}$ and Nisha Sharma ${ }^{2 *}$ \\ ${ }^{1}$ Department of Chemistry, Himachal Pradesh University, Shimla-171005, India \\ ${ }^{2}$ Govt. P.G. College, Sarkaghat-Mandi-175024, India
}

(Received July 29, 2014; revised December 29, 2014)

\begin{abstract}
In the view of the potential hazards associated with the widespread use of carbaryl insecticide, a new simple extractive spectrophotometric method has been developed for its determination in environmental samples viz. soil, water and foodstuffs for its safer and more effective use. The proposed method is based on the microwave assisted alkaline hydrolysis of the insecticide to methylamine. The later is measured as methyl isobutyl ketone (MIBK) extractable yellow nickel(II)-methyldithiocarbamate complex at $380 \mathrm{~nm}$ through the reaction with carbon disulfide and nickel(II) acetate. The insecticide can be determined in the linearity range from 2.01 to 60.3 $\mu \mathrm{g} \mathrm{mL}{ }^{-1}$ with a correlation coefficient of 0.996 . The method has been applied to the analysis of carbaryl in its commercial formulation and its recovery from vegetable and water samples for monitoring health hazards. Recoveries of the insecticide from vegetables and spiked water samples were good, ranging from 87.6-92.8\%, with RSDs ranging from $0.54-1.02 \%$. The method has also been validated for investigating the sorption of carbaryl on five soils with different characteristics to evaluate its leaching behaviour which is a measure of ground and surface water contamination. The leaching potential of the insecticide in terms of groundwater ubiquity score (GUS) has values in the range 1.8-2.2 classifying it as transition leacher hence it has potential to contaminate groundwater.
\end{abstract}

KEY WORDS: Carbaryl, Spectrophotometry, Environmental toxicity, Soil-sorption study, Leaching/GUS

\section{INTRODUCTION}

Carbaryl (I) - (1-naphthyl-N-methylcarbamate) is a broad spectrum third-most-used insecticide because of its high insecticidal activity and low mammalian toxicity. It controls over 100 species of insects on citrus, cotton, lawns, ornamentals, paddy, fruits and vegetable crops [1-3].

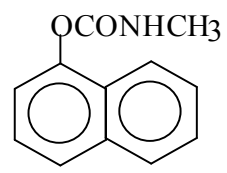

I

The environmental pollution caused by the extensive use of this indispensable chemical is of major concern because of its high toxicity. The acute oral $\mathrm{LD}_{50}$ for rats is $850 \mathrm{mg} / \mathrm{kg}$ [4]. It has been reported that carbaryl causes alteration of liver microsomal enzymes, neurotoxicity, immunotoxic effects, histopathological changes in the testis, haemoatopoietic alterations [5-9]. The extensive use of this insecticide poses a serious risk to both the environment and the human health due to direct exposure or through residues in the food and drinking water [10]. Carbaryl is the second most widely detected insecticide in the environmental samples viz foodstuffs and water [11].

The fate of pesticides is strongly influenced by their interactions with soil as the later is an ultimate reservoir of these chemicals irrespective of their application target. Following application, pesticides enter the soil and then into aquatic environment, via soil percolation and

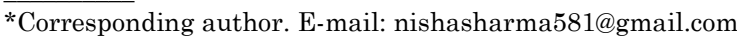


surface runoff and contaminate them. The pesticides in the soil get fractioned between soil solution phase (in the free form) and soil solid phase (in the bound form) through sorption. The sorption of pesticides affects their mobility, persistence, volatilization, toxicity and bioaccumulation which in turn influence the extent of surface and ground water contamination [12-13]. The knowledge of sorption characteristics of soil is necessary for predicting the mobility and fate of pesticides in the soil. This is because detoxification mechanism of the pesticides viz: degradation, metabolism and microbial uptake are operative on the unadsorbed fraction (free form) of the pesticide. Thus, from environmental point of view, sorption of carbaryl on soils is of great importance for the prediction of its movement in the soil and its subsequent contamination of ground and surface water. The determination of this insecticide in residues on foodstuffs and water samples and in its commercial formulation for the purpose of monitoring pollution and health hazards is equally important.

To accomplish above objectives, simple, sensitive and reliable methods of wide applicability are necessitated for the analysis of carbaryl. Of the various analytical methods viz. fluorescence, voltammetric, enzymatic, immunosensor, chromatographic, capillary zone electrophoresis [1, 14-19], the spectrophotometric methods [20-25] being simple, sensitive, reliable and find wide acceptance for the determination of carbaryl. Further, the spectrophotometric procedure can also tolerate little interfering material and the equipment being cheap in comparison to HPLC method commonly used for this insecticide and is easily accessible in most laboratories. The spectrophotometric methods reported in the literature require colored reagents and number of steps thus making methods tedious and time-consuming $[22,23]$. In the present work, a simple extractive method based on the microwave assisted alkaline hydrolysis of the carbaryl to methylamine and its subsequent reaction with carbon disulfide and nickel(II) acetate to form MIBK extractable yellow colored nickel(II) methyldithiocarbamate complex $\left[\mathrm{Ni}(\mathrm{DTC})_{2}\right]$ has been developed. The analysis is accomplished by measuring absorbance of the yellow MIBK extract at $380 \mathrm{~nm}$ against a reagent blank. The method has been suitably validated for the analysis of this insecticide in its commercial formulation and its recovery from grain, vegetable and water samples. The method has also been validated to study the sorption of this insecticide on five soils with different characteristics at two temperatures viz $20{ }^{\circ} \mathrm{C}$ and $30{ }^{\circ} \mathrm{C}$. The various sorption and thermodynamic parameters for the sorption of the insecticide have also been calculated.

\section{EXPERIMENTAL}

\section{Apparatus}

The spectrophotometric measurements have been made with carry100 Bio UV-Vis spectrophotometer (Varian Australia Pvt. Ltd. Mulgrave-Victoria, Australia). Domestic microwave oven (Samsung electronics, New Delhi, India) was used to carry out hydrolysis. The pH was made on Cyber Scam 2500 pH meter (Eutech instruments, Singapore). A shaking incubator (Genie (TM), Banglore, India) was used in Soil sorption study. A centrifuge (Labnet Z 150 A, Labnet International Inc Woodbride, NJ, USA) was used.

\section{Reagents and samples}

Acetonitrile (Merck, Mumbai, India) was kept over phosphorus pentaoxide $\left(5 \mathrm{~g} \mathrm{~L}^{-1}\right)$ and distilled twice. The analytical standard of carbaryl (supplied by the courtesy of Environmental Protection Agency EPA, NC, USA) was used and its stock solution $\left(10^{-3} \mathrm{M}\right)$ was prepared in acetonitrile. The purity of the sample was also established by reported method [26]. Boric acidphosphoric acid-acetic acid and sodium hydroxide buffer of $\mathrm{pH} \sim 4.5$ was prepared by mixing equal volumes $(23.3 \mathrm{~mL}$ ) of boric acid (Ranbaxy, SAS Nagar, Punjab, India, LR, $0.04 \mathrm{M}$ solution in water), phosphoric acid (Ranbaxy, SAS Nagar, Punjab, India, LR, 0.04 M solution in 
water) and acetic acid (Ranbaxy, SAS Nagar, Punjab, India, LR, $0.04 \mathrm{M}$ solution in water) followed by the addition of $30 \mathrm{~mL}$ of sodium hydroxide (Merck, Mumbai, India, LR, $0.2 \mathrm{M}$ solution in water) to make the final volume to $100 \mathrm{~mL}$ [27]. Potassium hydroxide (Merck, Mumbai, India, LR, 0.1 M solution in water), acetic acid (Ranbaxy, SAS Nagar, Punjab, India, LR, 0.1 M in water) were prepared in distilled water. Methyl isobutyl ketone (MIBK, Merck, Mumbai, India, AR) was used as received. Nickel(II) acetate (Central Drug House, Delhi, India, LR), its $0.01 \mathrm{M}$ solution in distilled water was prepared. Sodium sulfate anhydrous (Merck, Mumbai, India, AR), sodium chloride (Merck, Mumbai, India, AR) and carbon disulphide (Merck, Mumbai, India, AR) were used as received. Chloroform, commercial chloroform was allowed to stand over anhydrous potassium carbonate (AR) overnight and then distilled. The fraction distilling at $55{ }^{\circ} \mathrm{C}$ was collected. Sevin, $50 \mathrm{WP}$ (carbaryl formulation containing $50 \%$ active ingredient) used in the present investigation was procured from local market.

\section{Sample collection and preparation}

The soils samples used in the sorption study were collected with hand trowel at the depth of 0.5 $\mathrm{cm}$ from selected regions of Solan District of Himachal Pradesh, India. The soil samples were air dried and passed through $2 \mathrm{~mm}$ sieve to remove stones and large particles and kept in glass bottles prior to experiment. The soil characteristic viz $\mathrm{pH}$, organic carbon (\%), clay (\%) and cation exchange capacity (CEC) were determined by reported methods $[28,29]$ at the University of Horticulture and Forestry, Solan, Himachal Pradesh, India. The vegetable samples were procured from local farm houses and water samples collected from natural drinking water sources of the region were spiked with carbaryl insecticide for the recovery experiment.

\section{Preparation of calibration graph for pure compound}

Aliquots (0.1-3.0 mL) of standard solutions of carbaryl $\left(10^{-3} \mathrm{M}\right.$ in acetonitrile) were taken in 10 $\mathrm{mL}$ measuring flasks and diluted to $3 \mathrm{~mL}$ with acetonitrile. Each solution was mixed with aqueous potassium hydroxide $(1 \mathrm{~mL}, \sim 0.1 \mathrm{M})$ and $3 \mathrm{~mL}$ of distilled water. Each solution was mixed with one drop of carbon disulphide $(\sim 100 \mu \mathrm{L})$ and kept in microwave oven for $40 \mathrm{~s}(1000$ Watts). The hydrolyzed solution was then treated with acetic acid ( $2 \mathrm{~mL}, \sim 0.1 \mathrm{M}$ in water) to neutralize the excess alkali and also to make the condition slightly acidic. The solution was poured into a $100 \mathrm{~mL}$ separating funnel containing $1 \mathrm{~mL}, 0.01 \mathrm{M}$ nickel(II) acetate solution and $5 \mathrm{~mL}$ of buffer of $\mathrm{pH} \sim 4.5$ (a mixture of boric acid-phosphoric acid-acetic acid and sodium hydroxide). The contents of the funnel were equilibrated two times with MIBK using $4 \mathrm{~mL}$ each time and total volume of the MIBK extract was made to $10 \mathrm{~mL}$ with MIBK. The solution was dried with anhydrous sodium sulfate and the absorbance of yellow colored solution was measured at $380 \mathrm{~nm}$ against a reagent blank (Figure 1) and calibration curve was prepared (Figure 2) by plotting absorbance values against concentration. The calibration characteristics viz. Beer's law range, molar absorptivity, Sandell's sensitivity, slope and intercept values and correlation coefficient calculated from calibration graph are given in Table 1.

\section{Formulation analysis}

A wettable powder (WP) formulation "Sevin" containing 50\% active ingredient (carbaryl) procured from an authorized pesticide dealer was used. A single large sample of formulation equivalent to $10.05 \mathrm{mg}$ active ingredient was dissolved in $10 \mathrm{~mL}$ acetonitrile and diluted to a known volume $(50 \mathrm{~mL})$ with acetonitrile. Suitable aliquots of the above solution were taken and processed for analysis in the same manner as described above for pure compound. 


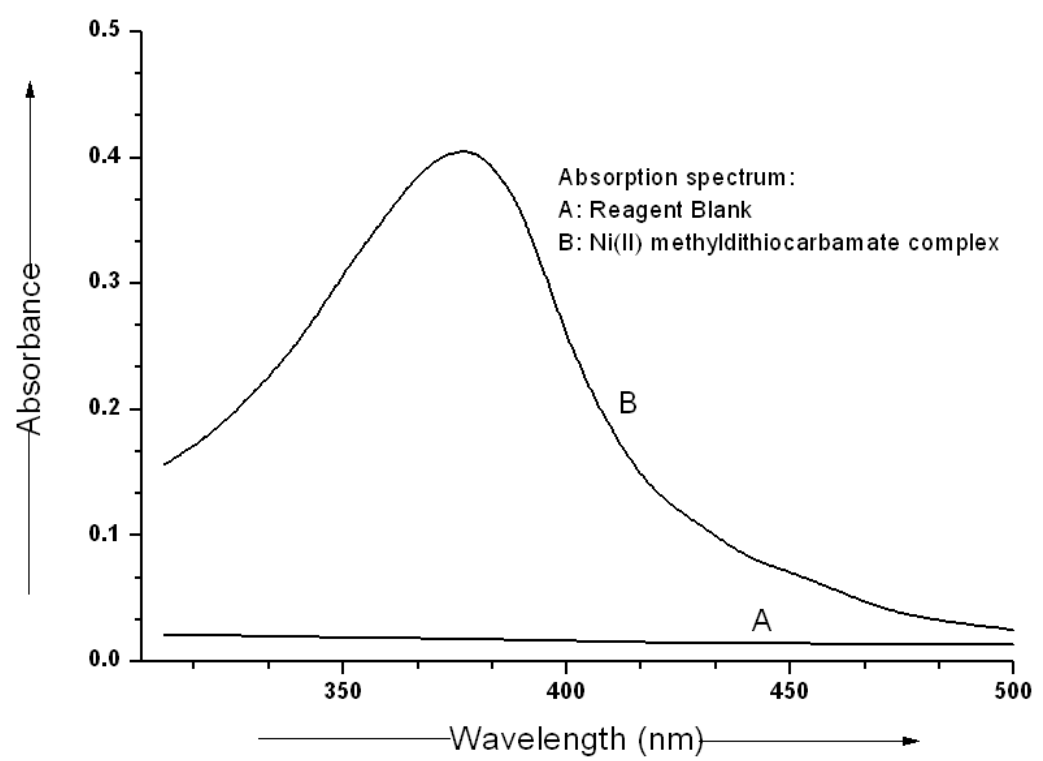

Figure 1. Absorption maximum for carbaryl.

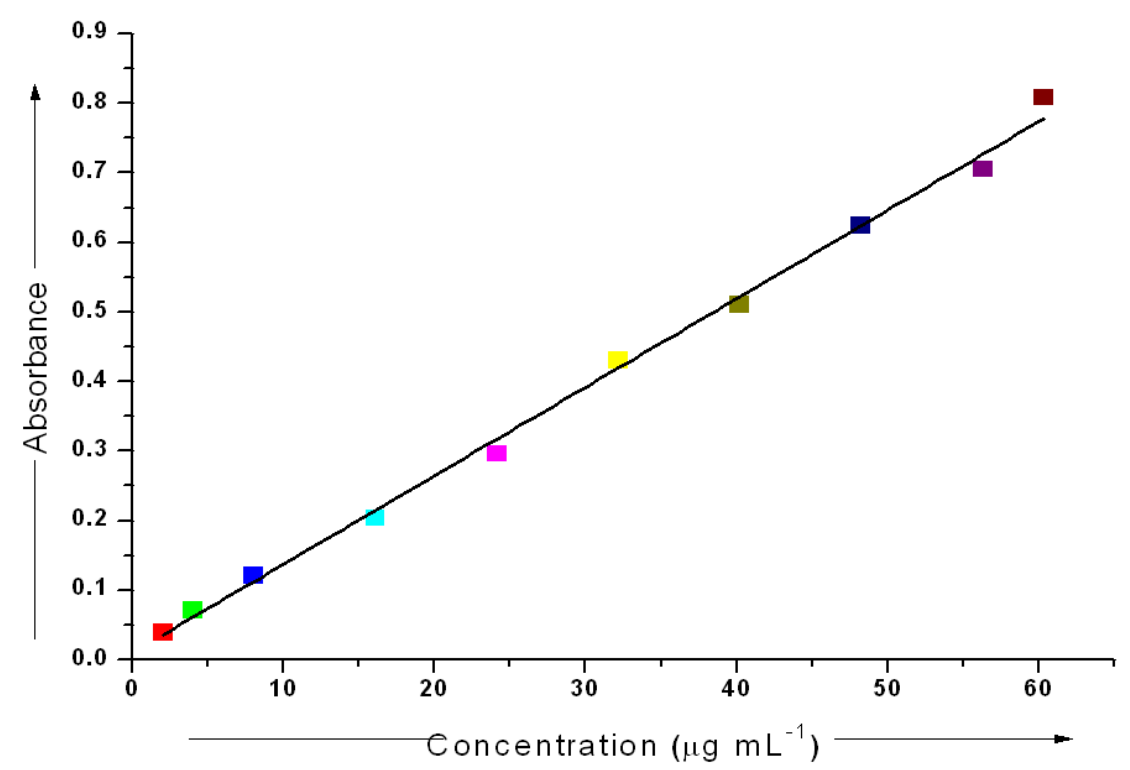

Figure 2. Calibration graph of carbaryl (as nickel(II) methyl dithiocarbamate) complex) at 380 nm. 
Table 1. Spectrophotometric determination of carbaryl as colored $\mathrm{Ni}(\mathrm{DTC})_{2}$ complex: calibration characteristics.

\begin{tabular}{|l|l|l|}
\hline S. No. & Optical characteristics & Corresponding value \\
\hline 1 & $\lambda_{\max }$ & $380 \mathrm{~nm}$ \\
\hline 2 & Beer's law range & $2.01-60.3 \mu \mathrm{g} \mathrm{mL}^{-1}$ \\
\hline 3 & Molar absorptivity $(\varepsilon)$ & $2.66 \times 10^{3} \mathrm{~L} \mathrm{~mol}^{-1} \mathrm{~cm}^{-1}$ \\
\hline 4 & Sandell's sensitivity & $0.076 \mu \mathrm{g} \mathrm{cm}^{-2}$ \\
\hline 5 & Stability of color & $120 \mathrm{~min}$ \\
\hline 6 & Slope & 0.013 \\
\hline 7 & Intercept & 0.011 \\
\hline 8 & Correlation coefficient $(\mathrm{R})$ & 0.996 \\
\hline
\end{tabular}

Determination of carbaryl in vegetable and water samples

A carbaryl standard solution was prepared by dissolving $10.05 \mathrm{mg}$ insecticide in $50 \mathrm{~mL}$ acetonitrile; this solution was further diluted 10 times with acetonitrile to a final concentration of $20 \mu \mathrm{g} \mathrm{mL} \mathrm{m}^{-1}$ carbaryl. Aliquots $(0.25-1.00 \mathrm{~mL})$ of this standard solution were added to $20 \mathrm{~g}$ portion of cauliflower and peas placed in glass containers. After thorough mixing with a Teflonblended mechanical stirrer, each sample was blended with $50 \mathrm{~mL}$ of chloroform in the same containers according to the general procedure of Schenk et al. [30]. The samples were filtered through coarse filter paper (Whatman Grade No. 4) and each filtrate was transferred into 250 $\mathrm{mL}$ separating funnels. Sodium chloride $(5 \mathrm{~g})$ was added to each sample, the contents were shaken for one minute and the phases were allowed to separate for $15 \mathrm{~min}$. The lower aqueous phase and any emulsion were discarded. Anhydrous sodium sulfate (4 g) was added and the funnel was shaken for $30 \mathrm{~s}$. The dried extract was filtered through coarse filter paper and filtrate evaporated to dryness on a water bath at $60{ }^{\circ} \mathrm{C}$. The residue was dissolved in $3 \mathrm{~mL}$ of acetonitrile and was processed for analysis as described above for the pure compound.

The proposed method has also been applied to the determination of the insecticide in spiked water samples. Aliquots $(0.25-1.00 \mathrm{~mL})$ of standard solution having concentration $20 \mu \mathrm{g} \mathrm{mL}^{-1}$ were added to $25 \mathrm{~mL}$ of water samples and were mixed thoroughly. The samples were extracted with chloroform and the extract processed for analysis in the same manner as described above.

\section{Interference study due to diverse metal ions}

Various aliquots of each diverse ion solution $\left(10^{-1} \mathrm{M}\right)$ were added to the standard solution containing $20 \mu \mathrm{g}$ of carbaryl prior to hydrolysis. Each solution was processed for analysis of carbaryl in the same manner as described for the compound.

\section{Soil sorption study}

Adsorption isotherms of carbaryl on five Indian soils with different soil characteristics were obtained by the batch equilibration technique using $50 \mathrm{~mL}$ of conical flask at two different temperatures, i.e. $20{ }^{\circ} \mathrm{C}$ and $30{ }^{\circ} \mathrm{C}$. Triplicate soil samples $(2 \mathrm{~g})$ were equilibrated with carbaryl formulation in the concentration range equivalent to $10.05-60.3 \mu \mathrm{g} \mathrm{mL}^{-1}$ of carbaryl on shaker (Genie (TM), Banglore, India) at $150 \mathrm{rpm}$ at respective temperature for $6 \mathrm{~h}$ equilibrium time (estimated time required for equilibrium to be reached between carbaryl adsorbed and in solution). After equilibration, the suspensions were centrifuged and the equilibrium concentrations $\left(\gamma_{\mathrm{e}}\right)$ were determined in supernatants by the spectrophotometric procedure described above. Adsorption isotherms were evaluated by using Freundlich's sorption equation which is written as 
$\mathrm{X}=\mathrm{K}_{\mathrm{f}} \gamma_{\mathrm{e}}^{\mathrm{nf}}$

where $X$ is the amount of pesticide adsorbed $\mathrm{mg} / \mathrm{kg}$ on the adsorbent; $\gamma_{\mathrm{e}}$ is the equilibrium solution concentration $\left(\mathrm{mgL}^{-1}\right) ; \mathrm{K}_{\mathrm{f}}$ and $\mathrm{n}_{\mathrm{f}}$ are sorption coefficients that characterize the sorption capacity of adsorbent. The sorption coefficients $K_{f}$ and $n_{f}$ are calculated from the least square methods applied to the linear form of the Freundlich's sorption equation

$\log X=\log K_{\mathrm{f}}+\mathrm{n}_{\mathrm{f}} \log \gamma_{\mathrm{e}}$

Another parameters for the sorption process viz. distribution coefficient or soil-sorption coefficient $\left(\mathrm{K}_{\mathrm{d}}\right)$, soil organic carbon partition coefficient $\left(\mathrm{K}_{\mathrm{oc}}\right)$ and Groundwater Ubiquity Score (GUS) have been calculated by using equations 3-5, respectively [31-33].

$\mathrm{K}_{\mathrm{d}}=\mathrm{X} / \gamma_{\mathrm{e}}$

$\mathrm{K}_{\mathrm{oc}}=\mathrm{K}_{\mathrm{d}} \times(100 / \% \mathrm{OC})$

GUS $=\log \left(\mathrm{t}_{1 / 2}\right)\left[4-\log \left(\mathrm{K}_{\mathrm{oc}}\right)\right]$

where $t_{1 / 2}$ is pesticide persistence (half life, days), OC is organic carbon content of the soil. GUS score is used to study the leaching behaviour of pesticides and these can be classified as leacher in which GUS values are higher than 2.8, transition with GUS values between 1.8 and 2.8 and non-leacher pesticides with GUS values lower than 1.8 [33].

The thermodynamic parameters viz. Gibb's free energy $\left(\Delta \mathrm{G}^{0}\right)$, enthalpy change $\left(\Delta \mathrm{H}^{\mathrm{o}}\right)$ and entropy change $\left(\Delta S^{\circ}\right)$ have also been calculated by using equations 6-8, respectively [34].

$\Delta \mathrm{G}^{\mathrm{o}}=-\mathrm{RT} \ln \mathrm{K}_{\mathrm{d}}$

$\ln \left\{\left(\mathrm{K}_{\mathrm{d}}\right)_{2} /\left(\mathrm{K}_{\mathrm{d}}\right)_{1}\right\}=\Delta \mathrm{H}^{\mathrm{o}} / \mathrm{R}\left\{\left(\mathrm{T}_{2}-\mathrm{T}_{1}\right) / \mathrm{T}_{1} \mathrm{~T}_{2}\right\}$

$\Delta S^{0}=\left(\left(\Delta H^{0}-\Delta G^{0}\right) / T\right.$

where $\mathrm{R}=$ gas constant, $\mathrm{T}=$ absolute temperature. All these parameters for the sorption of carbaryl on five Indian soils with different characteristics were calculated.

\section{RESULTS AND DISCUSSION}

\section{Standardization of the reaction conditions}

Effect of various experimental parameters on the development, stability and sensitivity of the color, vis-à-vis development of the proposed method has been studied before applying it to the analysis of carbaryl in commercial formulation, vegetables, water and soil sorption study. The experimental conditions optimized for developing the proposed method are:

\section{Effect of time of hydrolysis}

The optimum time required for complete hydrolysis (in microwave) of carbaryl to methylamine (dithiocarbamate) was obtained by varying the time of hydrolysis from 10-80 s and measuring corresponding absorbance of yellow nickel(II) complex at $380 \mathrm{~nm}$. It has been observed that maximum color intensity and its stability was obtained corresponding to $40 \mathrm{~s}$ hydrolysis time 
(Figure 3). Hydrolysis time less than $40 \mathrm{~s}$ gives less intensity of the color indicating non completion of hydrolytic reaction to form methylamine.

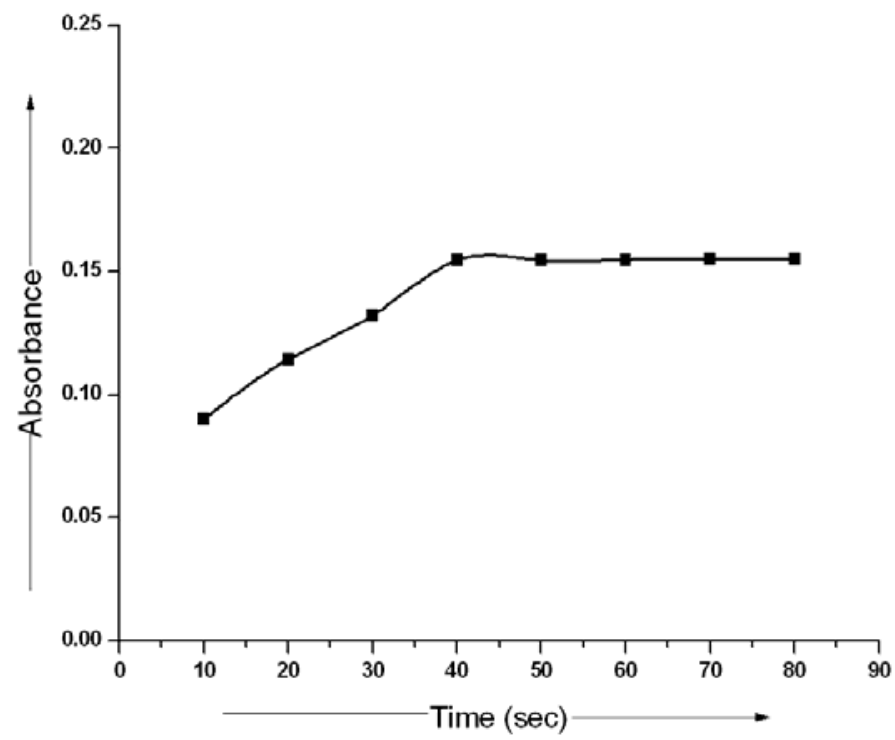

Figure 3. Effect of the time of hydrolysis in microwave on the absorbance value of carbaryl as (as nickel(II) methyl dithiocarbamate) complex) at $380 \mathrm{~nm}$ (concentration of carbaryl $=10 \mu \mathrm{g})$.

\section{Effect of $p H$}

It has been observed that maximum yellow color with high stability was obtained in acidic medium at $\mathrm{pH} \sim 4.5$ using universal buffer mixture (boric acid-phosphoric acid-acetic acidsodium hydroxide) [27]. Further, the extraction of colored product into Methyl isobutyl ketone is also best at this $\mathrm{pH}$. Methyl isobutyl ketone is an extracting solvent of choice because it is not only safe in comparison of commonly used toxic extracting solvents like benzene, chloroform, dichloromethane, ethyl acetate etc. and it relatively extract the colored product quantitatively from aqueous solution. Nickel(II) acetate (coloring reagent) remains in aqueous phase having no affinity for organic phase.

\section{Quantification}

Under the optimized experimental conditions, the proposed spectrophotometric method obeys Beer's law in the range of 2.01-60.3 $\mu \mathrm{g} \mathrm{mL}^{-1}$ for carbaryl. The method is quite sensitive and the molar absorptivity $(\varepsilon)$ and Sandell's sensitivity were found to be $2.66 \times 10^{3} \mathrm{~L} \mathrm{~mol}^{-1} \mathrm{~cm}^{-1}$ and 0.076 $\mu \mathrm{g} \mathrm{cm}^{-2}$ at $380 \mathrm{~nm}$, respectively. The method has subsequently been applied to the determination of carbaryl in commercial formulation, vegetables and spiked water samples; the recoveries of the insecticide from commercial formulation were in the range $93.2-96.6 \%$ of the nominal content with relative standard deviations (RSDs) in the range $0.4-1.5 \%$ (Table 2). The results have however been compared by an independent method [26]. The formulation analysis is essential not only to ensure the quality of the marketed samples of the insecticide but also to get reliable residue/sorption data. The recoveries of the insecticide from vegetables and spiked 
water samples were good, ranging from 87.6-92.8\%, with RSDs ranging from $0.54-1.02 \%$. The recoveries of carbaryl from vegetable and water samples are given in Table 3.

Table 2. Assay of a commercial formulation of carbaryl containing 50\% active ingredient (Sevin).

\begin{tabular}{|c|c|c|}
\hline \multirow{2}{*}{ Amount taken $(\mu \mathrm{g})$} & \multicolumn{2}{|c|}{${\text { Recovery }(\%)^{\mathrm{a}}}$} \\
\cline { 2 - 3 } & Present method & ${\text { Comparison } \text { method }^{\mathrm{b}}}^{\mathrm{a}}$ \\
\hline 4.02 & $93.8 \pm 0.8$ & $90.4 \pm 0.6$ \\
\hline 10.05 & $96.6 \pm 0.6$ & $94.2 \pm 1.2$ \\
\hline 20.10 & $93.2 \pm 0.4$ & $91.4 \pm 0.7$ \\
\hline 30.15 & $94.2 \pm 1.2$ & $92.6 \pm 0.8$ \\
\hline 60.30 & $95.5 \pm 1.5$ & $96.0 \pm 2.0$ \\
\hline
\end{tabular}

${ }^{a}$ Values are mean of five determinations with standard deviation $( \pm)$. ${ }^{b}$ Reference method [26].

Table 3. Recovery of carbaryl from vegetable and water samples.

\begin{tabular}{|c|c|c|c|c|c|c|}
\hline \multirow{2}{*}{$\begin{array}{c}\text { Carbaryl } \\
(\mu \mathrm{g})\end{array}$} & \multicolumn{5}{|c|}{ Recovery $(\%)^{\mathrm{a}}$} \\
\cline { 2 - 7 } & Cauliflower & Pea & Water & Cauliflower & Pea & Water \\
\hline 5.0 & $90.4 \pm 0.5$ & $90.4 \pm 0.6$ & $91.6 \pm 0.7$ & $86.2 \pm 0.8$ & $84.8 \pm 0.8$ & $89.4 \pm 0.8$ \\
\hline 10.0 & $89.3 \pm 0.7$ & $91.6 \pm 0.8$ & $90.2 \pm 0.8$ & $87.0 \pm 0.8$ & $85.2 \pm 0.84$ & $87.8 \pm 0.8$ \\
\hline 15.0 & $88.2 \pm 0.8$ & $90.8 \pm 0.7$ & $91.4 \pm 0.9$ & $85.2 \pm 0.9$ & $85.8 \pm 0.9$ & $85.6 \pm 1.0$ \\
\hline 20.0 & $87.6 \pm 0.9$ & $89.2 \pm 1.0$ & $92.8 \pm 1.0$ & $85.8 \pm 1.0$ & $84.8 \pm 1.0$ & $84.8 \pm 0.9$ \\
\hline
\end{tabular}

${ }^{\mathrm{a}}$ Values are mean of five determinations with standard deviation $( \pm)$. ${ }^{\mathrm{b}}$ Reference method [26].

\section{Proposed mechanism for the spectrophotometric method}

The present spectrophotometric method is based on the color reaction of methylamine (hydrolytic product of carbaryl) with carbon disulphide to form dithiocarbamate which reacts with nickel(II) acetate in water to form yellow colored $\left[\mathrm{Ni}(\mathrm{DTC})_{2}\right]$ complex which is extractable into MIBK that absorbs at $380 \mathrm{~nm}$ (Figure 1). That methylamine is formed from the alkaline hydrolysis of carbaryl [35] and reacts smoothly and quantitatively with carbon disulphide and nickel(II) acetate (in 2:1 molar ratio) forming metallic complex nickel(II) methyl dithiocarbamate, $\left[\mathrm{Ni}(\mathrm{DTC})_{2}\right]$ is quite well known [36-37]. The extraction process of the metallic complex in MIBK has been found to occur in acidic medium at $\mathrm{pH} \sim 4.5$ using universal mixture buffer (boric acid-phosphoric acid-acetic acid-sodium hydroxide) [27] and measured spectrophotometrically under optimized conditions at $380 \mathrm{~nm}$.

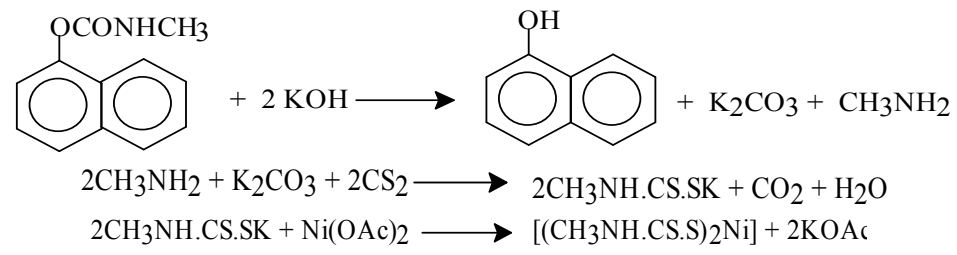

Scheme I. Proposed mechanism for the spectrophotometric method.

Interference study due to diverse metal ions

To assess the validity of the proposed method in soil sorption study, effect of various common ions on the determination of the insecticide was studied. Known amounts of the diverse ions $\left(10^{-1} \mathrm{M}\right)$ as their aqueous solutions were added to the standard solution containing $20 \mu \mathrm{g}$ of 
carbaryl prior to hydrolysis and the solution was analyzed for carbaryl by the proposed method. The method was found to be free from interferences due to common ions, e.g. $\mathrm{Na}^{+}, \mathrm{K}^{+}, \mathrm{Mg}^{2+}$, $\mathrm{Ca}^{2+}, \mathrm{Al}^{3+}, \mathrm{Pb}^{2+}, \mathrm{OAc}^{-}, \mathrm{PO}_{4}{ }^{3-}, \mathrm{NO}_{3}^{-}, \mathrm{NO}_{2}^{-}, \mathrm{CO}_{3}{ }^{2-}, \mathrm{SO}_{4}{ }^{2-}, \mathrm{Cl}^{-}$ions present in soil. The tolerance limit of these ions is given in Table 4 .

Table 4. Effect of various diverse ions on the determination of carbaryl.

\begin{tabular}{|c|c|}
\hline Diverse ions & Tolerance limit ${ }^{*}(\mathrm{mg} / \mathrm{L})$ \\
\hline $\mathrm{Na}^{+}, \mathrm{K}^{+}$, & 300 \\
\hline $\mathrm{Mg}^{2+}, \mathrm{Ca}^{2+}$ & 150 \\
\hline $\mathrm{Al}^{3+}$ & 100 \\
\hline $\mathrm{Pb}^{2+}$ & 50 \\
\hline $\mathrm{OAc}^{-}$ & 300 \\
\hline $\mathrm{PO}_{4}{ }^{-}$ & 150 \\
\hline $\mathrm{NO}_{3}{ }^{-}$ & 200 \\
\hline $\mathrm{NO}_{2}{ }^{-}$ & 200 \\
\hline $\mathrm{CO}_{3}{ }^{2-}$ & 200 \\
\hline $\mathrm{SO}_{4}{ }^{2-}$ & 150 \\
\hline $\mathrm{Cl}^{-}$ & 300 \\
\hline
\end{tabular}

${ }^{*}$ The amount causing an error $2 \pm 1.5 \%$.

With a view to evaluate the leaching potential of carbaryl a measure of ground and surface water contamination, its sorption have been studied on five soils with different characteristics (Table 5) by using batch-equilibrium method at two temperatures viz. $20{ }^{\circ} \mathrm{C}$ and $30{ }^{\circ} \mathrm{C}$, corresponding to the maximum temperature experienced in the field.

Table 5. Characteristics of the different Indian soils used in the sorption study of carbaryl.

\begin{tabular}{|c|c|c|c|c|}
\hline Soil sample & $\mathrm{pH}$ & Clay (\%) & Organic carbon (\%) & Cation exchange capacity (meq/100 g) \\
\hline I & 7.2 & 32.6 & 0.8 & 13.1 \\
\hline II & 7.6 & 18.2 & 0.9 & 12.9 \\
\hline III & 6.5 & 20.0 & 1.5 & 11.0 \\
\hline IV & 6.8 & 23.4 & 1.6 & 12.8 \\
\hline V & 7.6 & 14.1 & 0.7 & 11.6 \\
\hline
\end{tabular}

To study the sorption phenomena Freundlich sorption equation is most reliable because of possible rigorous derivation and more realistic assumptions compared with other equations [38]. The Freundlich adsorption isotherms are shown in Figures 4 and 5. These isotherms have been classified as S-type of Gile's classification (Table 6) according to the initial slope of the curve. S-type of isotherms represents a system where solid surface has higher affinity for the solvent than for solutes [11] (e.g. water competes strongly with solute for sorption sites). Freundlich's sorption coefficients $\mathrm{K}_{\mathrm{f}}$ and $\mathrm{n}_{\mathrm{f}}$ were calculated from the plot of $\log \mathrm{X}$ versus $\log \gamma_{\mathrm{e}}$ (Figure 6) from Freundlich's sorption equation and the results are presented in Table 6. The sorption coefficient $\mathrm{K}_{\mathrm{f}}$ represents the amount of pesticide adsorbed at an equilibrium concentration of 1 $m g L^{-1}$ and $n_{f}$ represents the variation in sorption with varying concentration of pesticide [13]. The observed values of $n_{f}$ were more than $1,(>1.0)$ in all five soils represent $\mathrm{S}$-type isotherms, which infer that there is competition between pesticides and water molecules for the sorption sites on surface of the adsorbents [39].

Other parameters such as soil sorption coefficients $\left(\mathrm{K}_{\mathrm{d}}\right)$, soil organic carbon partition coefficient $\left(\mathrm{K}_{\mathrm{oc}}\right)$, Gibb's free energy for sorption process $\left(\Delta \mathrm{G}^{\mathrm{o}}\right)$, enthalpy change $\left(\Delta \mathrm{H}^{\circ}\right)$ and entropy change $\left(\Delta \mathrm{S}^{\circ}\right)$ for the sorption of carbaryl were also calculated and are presented in Tables 6 and $7 . \mathrm{K}_{\mathrm{d}}$ for a pesticide is soil-specific and vary with texture and organic matter content of the soil, while the $\mathrm{K}_{\mathrm{oc}}$ is less soil specific [40] and is calculated by normalizing 
sorption coefficient $\left(\mathrm{K}_{\mathrm{d}}\right)$ with the organic carbon $(\mathrm{OC})$ content of the soil. The values of $\mathrm{K}_{\mathrm{d}}$ represents the extent of sorption and in general higher the $K_{d}$ value, greater is pesticide sorption. Of the five soils of different characteristics studied the decreasing sorption order is: Soil IV > Soil III $>$ Soil I $>$ Soil II $>$ Soil V.

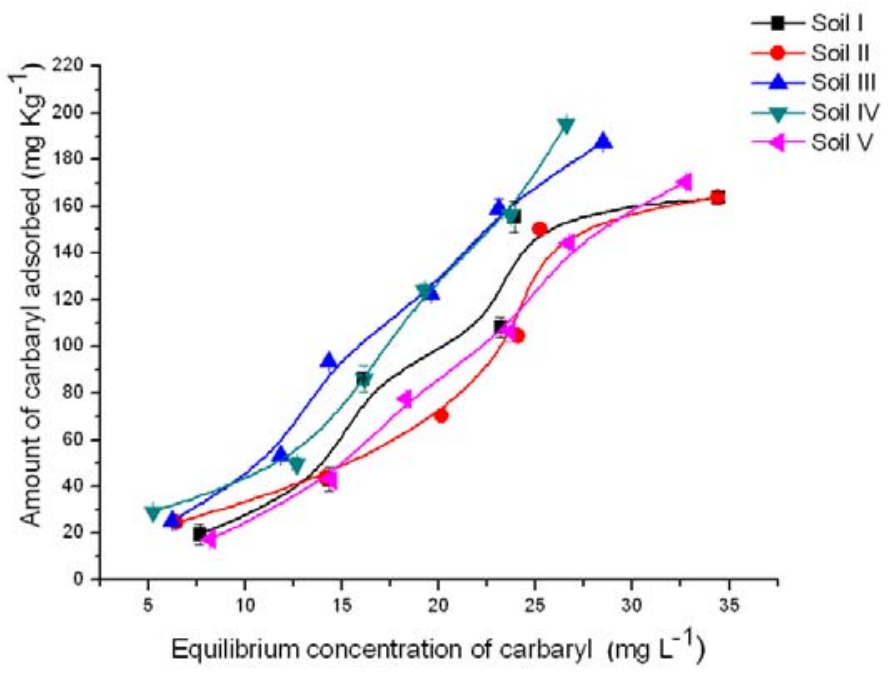

Figure 4. Adsorption isotherm of carbaryl sorption on soils I-V at $20{ }^{\circ} \mathrm{C}$ (error bars represent the standard deviation of three replicates).

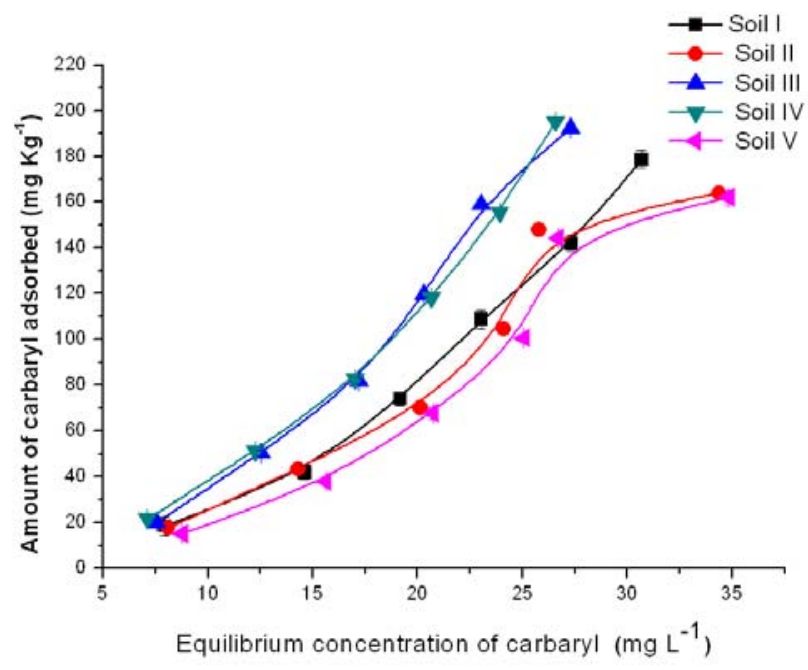

Figure 5. Adsorption isotherm of carbaryl sorption on soils $\mathrm{I}-\mathrm{V}$ at $30{ }^{\circ} \mathrm{C}$ (error bars represent the standard deviation of three replicates). 

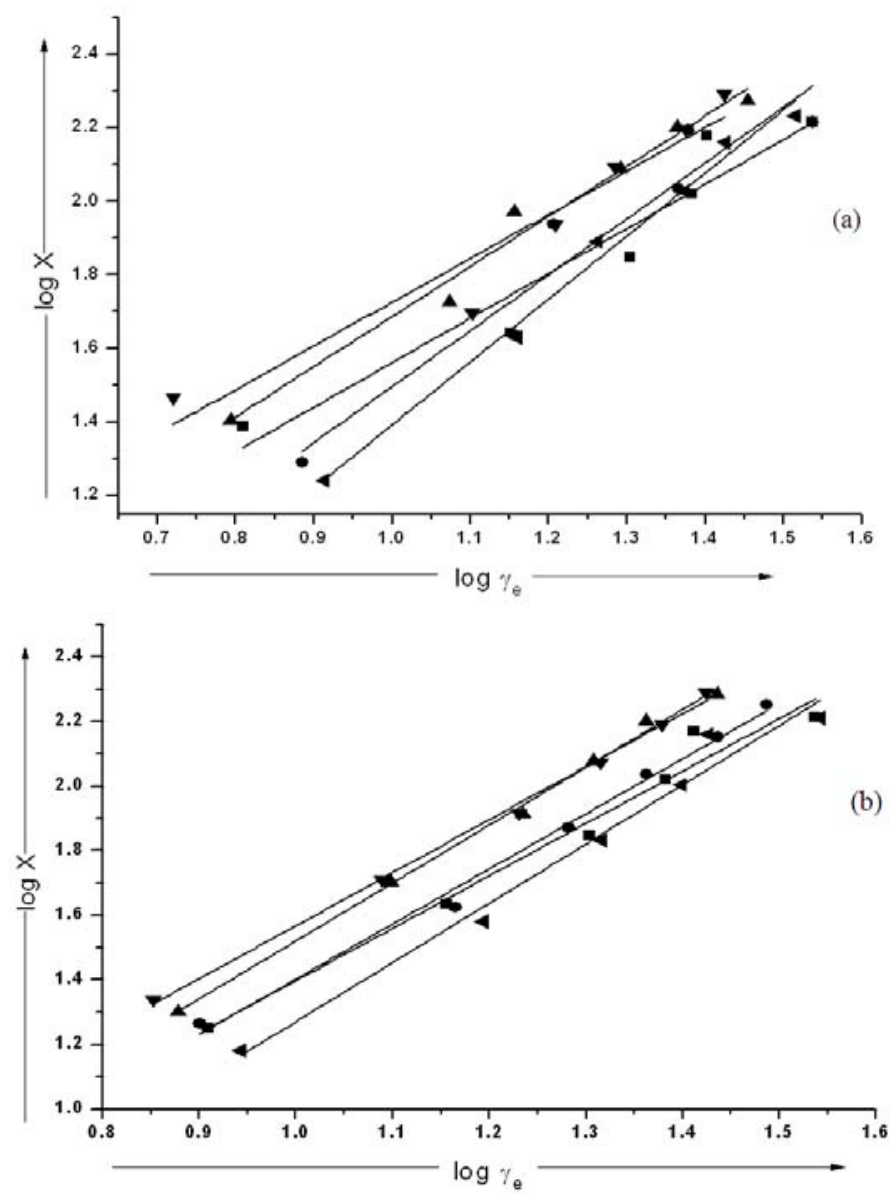

Figure 6. Plot of $\log \mathrm{X}$ versus $\log \gamma_{\mathrm{e}}$ for the evaluation of Freundlich's sorption coefficients $\mathrm{K}_{\mathrm{f}}$ and $\mathrm{n}_{\mathrm{f}}$ for five soils (a) at $20^{\circ} \mathrm{C}(\mathrm{b})$ at $30{ }^{\circ} \mathrm{C}$.

The higher sorption in the soils IV and III can be explained on the basis of the higher organic content in these soils [41]. The disparity among the $\mathrm{K}_{\mathrm{oc}}$ values obtained in these soils suggest that the sorption of carbaryl on five studied soils at $20{ }^{\circ} \mathrm{C}$ and $30{ }^{\circ} \mathrm{C}$ is not only influenced by $\mathrm{OC}$ content of the soil alone but also governed by some other factors. The value of cation exchange capacity (CEC) is directly proportional to hydrophobic nature of adsorbent. Greater is the value of CEC of the soil, its surface will be more hydrophobic and carbaryl being more hydrophobic (low water solubility) thus have higher sorption affinity for soils with higher CEC [42].

The sorption of carbaryl in five soils has been found maximum at $20{ }^{\circ} \mathrm{C}$ than at $30{ }^{\circ} \mathrm{C}$. This may be due to the fact that an increase in temperature might result in weakening of binding forces between carbaryl and soil particles. Similar results have also been reported in literature in the sorption studies of other pesticides [43]. 
Table 6. Sorption parameters for the sorption of carbaryl insecticide on five Indian soils at two different temperatures.

\begin{tabular}{|c|c|c|c|c|c|c|}
\hline Soil sample & $\mathrm{K}_{\mathrm{f}}$ & $\mathrm{n}_{\mathrm{f}}$ & $\mathrm{K}_{\mathrm{d}}$ & $\mathrm{K}_{\mathrm{oc}}$ & $\mathrm{GUS}$ & Adsorption isotherm \\
\hline \multicolumn{7}{|c|}{} \\
\hline I & 1.1 & 1.5 & 4.5 & 559.0 & 1.8 & S-type \\
\hline II & 2.2 & 1.2 & 4.2 & 471.1 & 1.9 & S-type \\
\hline III & 2.1 & 1.4 & 5.8 & 386.7 & 2.1 & S-type \\
\hline IV & 3.4 & 1.2 & 5.9 & 366.8 & 2.1 & S-type \\
V & 2.1 & 1.7 & 4.1 & 581.5 & 1.8 & S-type \\
\hline \multicolumn{7}{|l|}{} \\
\hline I & 2.0 & 1.7 & 4.1 & $30^{\circ} \mathrm{C}$ \\
\hline II & 1.7 & 1.6 & 3.9 & 436.3 & 2.0 & S-type \\
\hline III & 1.9 & 1.8 & 5.2 & 347.8 & 2.1 & S-type \\
\hline IV & 1.2 & 1.6 & 5.3 & 330.1 & 2.2 & S-type \\
V & 3.7 & 1.8 & 3.6 & 511.9 & 1.9 & S-type \\
\hline
\end{tabular}

The thermodynamic parameters for the sorption of carbaryl insecticide on five soils were also evaluated and are presented in Table 7. The $\Delta \mathrm{G}^{\mathrm{o}}$ values for sorption of carbaryl were negative at both temperatures. The magnitude of $\Delta \mathrm{G}^{0}$ also showed that the interactions of pesticides with the soil were thermodynamically spontaneous process and sorption occurred through a bonding mechanism. At constant temperature, the higher the value of $\Delta \mathrm{G}^{\mathrm{o}}$ the slower is the rate of sorption. The results obtained in the present study indicate an increase in the values of $\Delta \mathrm{G}^{\mathrm{o}}$ with temperature. Variation of $\Delta \mathrm{G}^{\circ}$ with temperature may be due to the increase in the degree of freedom of adsorbed molecules, which enhances desorption rather than sorption at higher temperatures $[34,44,45]$. The enthalpy change $\Delta \mathrm{H}^{\mathrm{o}}$ calculated for carbaryl were in the range (-5.60 to $\left.-9.47 \mathrm{~kJ} \mathrm{~mol}^{-1}\right)$. The negative values of $\Delta \mathrm{H}^{\mathrm{o}}$ indicated that the interaction of pesticides with the soil is an energetically favorable exothermic process. The $\Delta \mathrm{H}^{\mathrm{o}}$ values explain the binding strength of pesticides to the soil; the lower negative value of $\Delta \mathrm{H}^{\circ}$ indicates stronger binding. This indicates that the interactions between the pesticide and the studied soil samples were stronger at lower temperature [34, 44, 45]. The entropy change $\Delta S^{0}$ calculated for the adsorption of carbaryl on all five soils were negative indicated that the sorption involves stabilization, association, fixation or immobilization of the pesticide molecules as a result of which sorption decreased the degree of freedom, causing negative entropy effect and increasing the order of the system $[34,44,45]$.

Table 7. Thermodynamic parameters for the sorption of carbaryl on five Indian soils.

\begin{tabular}{|c|c|c|c|c|}
\hline Soil samples & \multicolumn{2}{|c|}{$\Delta \mathrm{G}^{\mathrm{o}}\left(\mathrm{kJ} \mathrm{mol}^{-1}\right)$} & $\Delta \mathrm{H}^{\mathrm{o}}\left(\mathrm{kJ} \mathrm{mol}^{-1}\right)$ & $\Delta \mathrm{S}^{\circ}\left(\mathrm{kJ} \mathrm{K}^{-1} \mathrm{~mol}^{-1}\right)$ \\
\hline & $20^{\circ} \mathrm{C}$ & $30^{\circ} \mathrm{C}$ & $25^{\circ} \mathrm{C}$ & $25^{\circ} \mathrm{C}$ \\
\hline I & -3.65 & -3.58 & -5.84 & -0.0075 \\
\hline II & -3.52 & -3.45 & -5.60 & -0.0071 \\
\hline III & -4.28 & -4.16 & -7.78 & -0.0119 \\
\hline IV & -4.31 & -4.19 & -7.82 & -0.0120 \\
\hline V & -3.42 & -3.22 & -9.47 & -0.0206 \\
\hline
\end{tabular}

A number of models are available to evaluate the leaching potential of pesticides and associated surface and ground water contamination. The GUS is the most commonly used model which relates pesticide persistence (half life) and $\mathrm{K}_{\mathrm{oc}}$. The leaching potential of the insecticide in terms of GUS index was evaluated by using the experimentally observed $\mathrm{K}_{\mathrm{oc}}$ value for each soil of different characteristics and the reported half life of carbaryl [33]. The GUS score for carbaryl has been observed in the range 1.8-2.2 which classifies it as a transition insecticide and has a potential to contaminate ground and surface water [46]. This observation calls for the 
judicious use of this insecticide by adjusting the application dose according to the soil type especially near the water bodies. Also the soils should be amended with farmyard manure and compost which are rich in organic matter content in order to increase the insecticide retention and thus reducing its mobility. The later application will also improve the soil fertility and health by serving as a source of soil nutrients.

\section{CONCLUSION}

The proposed method is simple, rapid, reliable and cost effective and is free from interferences of most of the common ions present in the soil. The microwave assisted hydrolysis of the carbaryl insecticide helps in reducing time from minutes to seconds, instantaneous development of the color coupled with well established stoichiometry of the reaction are some other salient features of the method. The recoveries of carbaryl from water and foodstuffs are good. The leaching potential of carbaryl in terms of GUS score (1.8-2.2) classify it as a transition leacher, suggesting its weak sorption on the soils leading to its greater mobility, thus having potential to leach to the ground water.

\section{REFERENCES}

1. Kim, G.E.; Choi, S.S.; Kang, M.; Ferdous, T.; Choi, J.H.; Lee, S.H. Malaysian J. Chem. 2009, 11, 1 .

2. Elsabawy, K.M.; Refat, M.S. Arch. App. Sci. Res. 2011, 3, 413.

3. Mahajan, R.; Paul, S.; Singh, S.; Mahajan, R. Int. J. Clin. Surg. Adv. 2014, 2, 72.

4. Dikshith, T.S.S. Handbook of Chemicals and Safety, CRS Press: Boca Raton; 2010; 161.

5. Jorsaraei, S.G.A.; Maliji, G.; Faraji, A.A. Environ. Toxicol. Pharmacol. 2014, 38, 838.

6. Cakıci, O. Bull. Environ. Contam. Toxicol. 2013, 91, 96.

7. Bhaskara, B.L.; Nagaraja, P. E-J. Chem. 2006, 3, 250.

8. Patnaik, L.; Patra, A.K. J. App. Sci. Environ. Manag. 2006, 10, 5.

9. Wang, H.P.; Liang, Y.J.; Sun, Y.J.; Hou, W.Y.; Chen, J.X.; Long, D.X.; Xu, M.Y.; Wu, Y.J. Environ. Toxicol. 2014, 29, 1193.

10. Arias-Estevez, M.; Lopez-Periago, E.; Martinez-Carballo, E.; Simal-Gandara, J.; Mejuto, J.C.; Garcia-Rio, L. Agric. Eco. Environ. 2008, 123, 247.

11. Oliveira, M.F.; Johnston, C.T.; Premachandra, G.S.; Teppen, B.J.; Li, H.; Laird, D.A.; Zhu, D.; Boyd, S.A. Environ. Sci. Technol. 2005, 39, 9123.

12. Wauchope, R.D.; Yeh, S.; Linders, J.B.H.J.; Kloskowsky, R.; Tanaka, K.; Rubin, Bl. Pest Manag. Sci. 2002, 58, 419.

13. Jaya, M.; Singh, S.B.; Kulshrestha, G.; Arya, S. Pest. Res. J. 2009, 21,101.

14. Koc, F.; Yigit, Y.; Das, Y.K.; Gurel, Y.; Yarali, C. J. Food Drug Anal. 2008, 16, 39.

15. Shoeibi, S.; Amirahmadi, M.; Yazdanpanah, H.; Pirali-Hamedani, M.; Pakzad, S.R.; Kobarfard, F. Iran. J. Pharm. Res. 2011, 10, 119.

16. Tehrani, M.S.; Givianrad, M.H.; Akhoundi, L.; Akhoundi, M. Anal. Methods 2013, 5, 2406.

17. Rocha-Gaso, M.I.; Garcia, J.V.; Garcia, P.; March-Iborra, C.; Jimenez, Y.; Francis, L.A.; Montoya, A.; Arnau. A. Sensors 2014, 14, 16434.

18. Codognoto, L.; Tanimoto, S.T.; Pedrosa, V.A.; Suffredini, H.B.; Machado, S.A.S.; Avaca, L.A. Electroanal. 2006, 18, 253.

19. Lin, X.; Hong, Q.; Wu, X.; Guo, L.; Xie, Z. J. Chromatogr. Sci. 2008, 46, 615.

20. Zare-Shahabadi, V.; Abbasitabar, F.; Akhond, M.; Shamsipour, M. J. Braz. Chem. Soc. 2013, 24, 1561.

21. Chiba, M. J. Agric. Food Chem. 1981, 29, 118.

22. Manjubhashini, A.B.; Raman, G.K.; Kumar, S.; Chiranjeevi, P. Talanta 2003, 59, 1015. 
23. Kumar, K.S.; Suvardhan, K.; Chiranjeevi, P. Anal. Lett. 2005, 38, 697.

24. Murthy, P.K.; Sulochana, M.; Naidu, N.V. Der. Pharma. Sin. 2012, 3, 224.

25. Ghisellini, G.; Foschini, L.; Volonteri, M.; Haardt, F.; Burlon, D.; Tavecchio, F. Chin. J. Chem. 2006, 24, 1095.

26. Stansbury, Jr., H.A.; Miskus, R.; Zweig, G. Analytical Methods for Pesticides, Plant Growth Regulators and Food Additives, Academic Press: New York; 1964; 437.

27. Lurie, Ju Handbook of Analytical Chemistry, MIR Publishers: Moscow; 1975; p 263.

28. Jackson, M.L. Soil Chemical Analysis, Prentice-Hall Publisher: Englewood Cliffs; 1967; pp 57, 205.

29. Walkey, A.; Black, I.A. Soil Sci. 1934, 37, 29.

30. Schenck, F.J.; Lehotay, S.J.; Vega, V. J. Sep. Sci. 2002, 25, 883.

31. Vischetti, C.; Marucchini, C.; Leita, L.; Cantone, P.; Danuso, F.; Giovanardi, R. Eur. J. Agron. 2002, 16, 231.

32. Raturi, S.; Islam, K.R.; Caroll, M.J.; Hill, R.L. J. Environ. Sci. Health Part B 2005, 40, 697.

33. Papa, E.; Castiglioni, S.; Gramatica, P.; Nikolayenko, V.; Kayumov, O.; Calamari, D. Water Res. 2004, 38, 3485.

34. Bhardwaj, D.; Sharma, P.; Tomar, R. Ind. J. Chem. 2007, 46, 1796.

35. Robert, T.R.; Hutson, D.H.; Jewess, P.J.; Lee, P.W.; Nicholls, P.H.; Plimmer, J.R.; Metabolic Pathways of Agrochemicals Part 2, Fungicides and Insecticides, Royal Society of Chemistry: Cambridge; 1999; p 16.

36. Verma, B.C.; Chauhan, S.; Sharma, N.; Sharma, U.; Sharma, D.K.; Sood, A. Talanta 1986, 33,703 .

37. Verma, B.C.; Rao, B.G.; Kumar, P.; Sharma, N.K.; Sharma, D.K.; Sharma, N. Nat. Acad. Sci. Lett. 1988, 11, 179.

38. Kuisi, M.A. Environ. Geol. 2002, 42, 666.

39. Cruz-Guzman, M.; Celis, R.; Hermosin, M.C.; Koskinen, W.C.; Cornejo, J. J. Agric. Food Chem. 2005, 53, 7502.

40. Chen, J.P.; Pehkonen, S.O.; Lau, C.C. Coll. Surf.: Physiochem. Eng. Asp. A. 2004, 240, 55.

41. Kumar, M.; Philip, L. Chemosphere 2006, 62, 1064.

42. Pal, O.R.; Vanjara, A.K. Sep. Puri. Technol. 2001, 24, 167.

43. Farahani, G.H.N.; Zakaria, Z.; Kuntom, A.; Omar, D.; Ismail, B.S. Adv. Environ. Biol. 2007, $1,20$.

44. Shariff, R.M. Int. J. Chem. 2011, 3, 134.

45. Shariff, R.M.; Shareef, K.M. Int. J. Sci. Eng. Res. 2011, 2, 1.

46. Hiller, E.; Khun, M.; Zemanova, L.; Jurkovic, L.; Barta, M. Plant Soil Environ. 2006, 52, 550. 